\title{
WPS3531
}

\section{Geopolitical Interests and Preferential Access to U.S. Markets*}

\author{
Daniel Lederman ${ }^{\dagger}$ and Çaglar Özden
}

\begin{abstract}
The United States imports around $25 \%$ of its merchandise under some form of preferential trade regime. This paper examines both the origins and the consequences of U.S. trade preferences in the context of the gravity model of international trade. The main contributions of the paper are threefold. First, it provides estimates of the impact of preferential trade regimes in terms of access to U.S. markets while controlling for geostrategic interests that determine the countries that are offered commercial preferences. Second, we consider not only country eligibility but also the extent of utilization of these programs. Third, we provide new estimates of the impact of transport and transactions costs beyond distance. In the standard gravity estimation, we find that beneficiaries of these preferences, except GSP, export between 2-3 times more than the excluded countries, after controlling for country and product characteristics. Nonetheless, the estimated effects of these programs are lower when controlling for utilization ratios and selection biases due to the correlation between geopolitical interests and the standard explanatory variables used in the gravity model of trade, such as countries' geographic distance from the U.S.
\end{abstract}

${ }^{*}$ We would like to thank Caroline Freund, Bernard Hoekman, Marcelo Olarreaga, Arvind Panagariya, Eric Reinhardt, Pablo Sanguinetti, Maurice Schiff, Luis Servén, Jerry Thursby, Shang-jin Wei for comments and Evelina Mengova for research assistance. Carlos Felipe Jaramillo suggested that we analyze the impact of FTAs in a gravity model approach. This research was partly funded by the Regional Studies Program of the Latin America/Caribbean unit of the World Bank. The findings, interpretations and conclusions expressed in this paper are entirely those of the authors. They do not necessarily represent the views of the World Bank, its executive directors, or the countries they represent.

${ }^{\dagger}$ Corresponding author. World Bank, Office of the Chief Economist for Latin America / Caribbean. Mailing address: World Bank Mailstop: I-8-801. 1818 H Street NW Washington, DC 20433. E-mail: dlederman@worldbank.org. Phone: 202-473-9015.

${ }^{\ddagger}$ World Bank and Dept of Economics, Emory University. 


\section{Introduction}

The United States, one of the strongest supporters of multilateral liberalization in the postWorld War II era, today imports around $25 \%$ of its foreign merchandise under some form of preferential trade program. Among these are Free Trade Areas (FTAs), such as NAFTA, and many unilateral preference programs, such as the Generalized System of Preferences (GSP) and the Caribbean Basin Initiative $(\mathrm{CBI})^{1}$. The absolute and relative effects of these various programs are of great interest to many U.S. trading partners, both beneficiaries and excluded countries ${ }^{2}$.

The effects of preferential trade arrangements, especially bilateral and regional agreements, have been extensively analyzed in the literature ${ }^{3}$. The gravity model, over the last decade, proved to be one of the successful tools in this literature. In their review article on regionalism and gravity models, Greenaway and Milner [2002] cite over 25 papers, starting with the influential work of Aitken [1973] and continuing with Frankel, Stein and Wei [1995]. The standard approach has been to represent membership in a specific regional trade agreement through a dummy variable in the bilateral gravity equation ${ }^{4}$. Although they vary across papers, the general result is that regional agreements have positive effects on the volume of bilateral trade among member countries.

We use the gravity model in a similar fashion and focus on several issues that have not been properly addressed. First, we emphasize the special role played by the U.S. political and geostrategic motivations in determining which countries receive eligibility. Endogeneity of preferential agreements is generally an ignored issue, yet a critical one since the granting

\footnotetext{
${ }^{1}$ The preferential trade programs we analyze are FTAs (NAFTA and Israel), Generalized System of Preferences (GSP), Caribbean Basin Initiative (CBI), Andean Trade Promotion Act (ATPA), and the African Growth and Opportunity Act (AGOA).

${ }^{2}$ The latest FTA to be signed by the US was CAFTA (U.S.-Central America Free Trade Agreement) which includes El Salvador, Guatemala, Honduras, Nicaragua and Costa Rica.

${ }^{3}$ See Bhagwati, Krishna \& Panagariya [1999] for a compilation of important papers and Schiff and Winters [2003] for an extensive review.

${ }^{4}$ Other studies include various other dummy variables to analyze the effect of comomn history, political relations etc. See Frankel [1997] for a survey.
} 
and removal of preference eligibility is quite often a political decision. Both of its neighbors and a close political ally were the first countries to sign FTAs with the US. CBI and CAFTA are specially designed for a region that the US considers strategically important. Andean preferences are part of the war against drugs; political conditions are explicitly stated as eligibility criteria for the GSP and the AGOA. Furthermore, recipients' trade performance affects the US government's decisions to extend or cancel preferences through explicit measures and lobbying of domestic industries. We address these potential endogeneity and selection bias problems and provide new estimates of the impact of trade preferences on U.S. imports.

Second, we consider not only country eligibility to assess the impact of various programs, but also the extent of their utilization, which depends on the relevant rules of origin (ROO) and other compliance costs. The restrictive role of the ROO is frequently mentioned in the policy literature but seldom analyzed empirically ${ }^{5}$. When we take into account both the restrictiveness of the ROO and the endogeneity of preference eligibility, the estimated impact of preferential market access declines considerably, from around $100-200 \%$ to a 20 $80 \%$ increase, depending on the program.

Since trade flows can be affected by transport and transactions costs that vary across products and countries, we provide estimates of the impact of these costs beyond controlling for geographic distance, a variable that is tightly correlated with U.S. geostrategic interests and a determinant of the probability of receiving preferences. In the treatment regressions that control for preference eligibility, distance variable becomes statistically irrelevant in determining trade volumes while transport costs remain robustly significant.

The rest of the paper is organized as follows. Section 2 provides a brief description of the various trade preferences offered by the U.S. Section 3 presents the basic econometric model and describes the relevant indicators and data, including the proxy for the utilization of the preferential programs. Section 4 discusses the various estimation results, and the main findings are summarized in the concluding section 5 .

\footnotetext{
${ }^{5}$ The utilization ratio is zero for numerous tariff lines under the GSP and only $25 \%$ on average. Even for NAFTA, the utilization ratio is 63\% in 1997 and it is below 50\% for Caribbean and Andean preferences.
} 


\section{Trade Preferences Offered by the United States}

In this paper, we analyze both reciprocal arrangements such as FTAs (NAFTA and Israel) and unilateral preference programs such as the Generalized System of Preferences (GSP), Caribbean Basin Initiative (CBI), Andean Trade Promotion Act (ATPA), and the African Growth and Opportunity Act (AGOA). Israel was the first country to sign an FTA with the US in 1985 and the long phase-out periods for certain tariff lines were finally completed by 1995. NAFTA, the most important FTA for the U.S. to date, came into force in 1994. It also contains various tariff phase-out periods and rather restrictive rules of origin requirements. Since then, the U.S. signed FTA agreements with Jordan, Singapore, Chile, and recently in 2004 with five Central American countries. These agreements were not in place in 2001 and therefore they are not included in our dataset.

Beneficiary countries are not required to reciprocate and lower their trade barriers on their imports from the US in the case of unilateral preference programs, among which the Generalized System of Preferences (GSP) is the oldest one. It was established under GATT auspices, whereby many developed countries, including the US and the EU, voluntarily extend preferences to developing countries. The US implemented its GSP program in 1974 and it covers over 150 countries in our sample. While customs unions and free trade areas are required by the GATT to cover "substantially all trade" and have internal tariffs of zero, no such restrictions apply to unilateral programs. Donor countries have complete discretion on country and product eligibility, granting and removal criteria as well as preference margins. That is why politically sensitive sectors such as apparel and agriculture are excluded from GSP and successful exporters are routinely removed as it was the case with several East Asian countries, such as Korea, Singapore and Hong Kong, in 1989.

The Caribbean Basin Initiative (CBI), Andean Trade Promotion Act (ATPA), and Africa Growth and Opportunity Act (AGOA) are also unilateral programs and have their legal basis on the same principles as the GSP. However, they are much more generous in terms of product coverage and involve stronger political commitments from the US. CBI was launched in 1986 
and has continuously evolved. One of the most important changes was the expansion of the apparel preferences with the Caribbean Basin Trade and Promotion Act of 2000. ATPA was first signed into law in 1991 and was renewed in 2001 under the new title of Andean Trade Promotion and Drug Eradication Act. The main change was the extension of dutyfree access to apparel and footwear exports from Andean countries that fulfill certain rules of origin. The final program in our data is AGOA which grants duty and quota free access to sub-Saharan countries since 2000. 33 countries in our sample enjoy AGOA benefits. Liberal rules of origin requirements in apparel, even compared to NAFTA, CBI and ATPA, are its most important provisions .

\section{Econometric Model and Variables}

The gravity model has been used successfully since the early 1970s (e.g., Aitken [1973]) ${ }^{6}$ to explain the volume of trade between pairs of countries using the distance between them and their income levels ${ }^{7}$. The basic gravity equation is frequently enhanced with various other variables that influence bilateral trade volume, such as sharing a common language or a border, being landlocked and membership in international organizations (see, among others, Feenstra, Markusen, and Rose [2001]; Rose [2003]). Among new applications of the gravity model are analysis of the impact of currency unions (Rose [2001] and international institutions on trade volume (Rose [2003] and Wei and Subramanian [2003]).

We modify the standard gravity model along several other dimensions to estimate and quantify the effects of the different U.S. preference programs. The main additions is the inclusion of variables to capture the impact of trade preference program as explained below. Second, we estimate the gravity equation at the product level (two-digit HS classification)

\footnotetext{
${ }^{6}$ Anderson [1979] asserted that "Probably the most successful empirical trade device of the last twenty-five years is the gravity equation." See also the literature review by Anderson and Van Wincoop [2003b].

${ }^{7}$ Its empirical success lead to efforts to provide theoretical foundations to the gravity equation. Anderson [1979] is considered as one of the earliest attempts followed by Bergstrand [1989], Anderson and van Wincoop [2003a] and Eaton and Kortum [2003].
} 
to capture the varying treatment of different product categories under each preference program. Third, we include a variable, in addition to distance, to capture transport and various transactions costs that vary not only across countries but also across products. We explain the construction of all of our variables in greater detail in the next subsection.

The specification of the empirical gravity equation is the following:

$$
\begin{aligned}
\ln \left(X_{i j t}\right)= & \alpha+\beta_{1} \ln \left(\text { Income }_{i t}\right)+\beta_{2} \ln \left({\text { Income per } \left.\text { capita }_{i t}\right)}\right. \\
& +\beta_{3} \ln \left(\text { Distance }_{i}\right)+\beta_{4} \ln \left(\text { Area }_{i}\right)+\beta_{5} \text { Border }_{i} \\
& +\beta_{6}{\text { WTO } \text { Member }_{i t}+\beta_{7} \text { Common Language }_{i}} \\
& +\beta_{8} \text { Island }_{i}+\beta_{9} \text { TransportCost }_{i j t} \\
& +\sum_{k} \delta_{k} \text { Preference }_{i j t k}+\sum_{j} \sigma_{j} P_{j}+e_{i j t}
\end{aligned}
$$

$X_{i j t}$ is the value of total exports from country $i$ in product category $j$ to the United States in year $t$. The impact of preference program $k$ is captured with the variable Preference $_{i j t k}$. We also add product fixed effects denoted by the variables $P_{j}$. This variable aims to capture various differences among product categories, such as the MFN tariff rates. We estimate the above equation separately for 1997 and 2001 to better assess the impact of several preference programs that came into effect in 2000. We have 173 countries and 98 product categories for a total of 16,954 observations per year in the dataset tough some of the data is missing for some of the very small countries. We should note that the majority of the studies in the literature use aggregate trade volume, rather than sectoral trade. However, there are also many exceptions that use disaggregated trade volume such as Bergstrand [1989], Feenstra, Markusen and Rose [2001] and Evenett and Keller [2003]. Furthermore, Anderson [1979]'s theoretical justification for the gravity estimation includes a multi-sector model. 


\subsection{Data Description}

The following are various variables that affect trade and have been used in gravity equations in the literature. Income and income per capita are real GDP and real GDP per capita in year $t$ for country $i$. Distance is between country $i$ and the United States in kilometers. Area of country $i$ is measured in square kilometers. Border is a dummy variable which is 1 if the country shares a border with the US - in our case, only Mexico and Canada. WTO member is a dummy variable which is 1 if the country $i$ was in the WTO in year $t$. Of the 173 countries in our sample, 142 and 152 were members in 1997 and 2001, respectively. Common language is dummy variable with value is 1 if country $i$ has English as a commonly spoken language. Island is another dummy variable and is 1 if the country $i$ is an island. The majority of the above data for these variables is provided by Rose $[2003]^{8}$ tough we added some missing observations from the World Development Indicators [2002] of the World Bank. Sample statistics are provided in Table 1a.

The trade flows, on the other hand, are from USITC, which provides extremely detailed data on various measures of bilateral trade of the United States with each trading partner under each preference program at the tariff line level ${ }^{9}$. The export value, $X_{i j t}$, is the Customs Value of all exports from $i$ to the United States in category $j$ in year $t$ (1997 or 2001).

Due to the lack of data, most papers in the literature use the bilateral distance to measure transport and transaction costs. However, when we use distance as a proxy for all such costs, we are explicitly assuming that these are uniform across a wide range of products and that the cost of one kilometer is the same across countries. Our proxy Transport Costs is constructed as the natural log of the ratio of CIF value (customs, insurance freight) to the customs value. It is approximately the cost of insurance and freight as a percent of the customs value of the product and has mean value of $9 \%$ in both years. This variable enables us to identify sector-specific and country-specific transport and other transactions costs, as opposed to

\footnotetext{
${ }^{8}$ Andrew Rose generously provides this data at http://faculty.haas.berkeley.edu/arose/RecRes.htm

${ }^{9}$ See www.usitc.gov.
} 
other costs associated with geographic distance.

\subsection{How to Measure Preferences}

For the purpose of our analysis, it is crucial to accurately construct a measure of Preferences. The United States has various preference programs in place as discussed in a previous section. We construct different variables for each program (FTA, GSP, CBI, Andean, AGOA) to identify their absolute and relative impact on the exports of the beneficiary countries. Preference eligibility is determined at the tariff line level in each program. For example, in the case of GSP, exports of more than 6000 tariff lines with positive MFN tariffs are eligible to enter with zero tariffs and 127 countries in our sample receive this preference. Although, it is possible that not every country is eligible for trade preferences in a given product due to the so-called competitive need limits, this is rather rare $^{10}$. There are 21 countries eligible for CBI, 4 for Andean and 33 for AGOA preferences. There is no overlap between the countries in CBI, Andean and AGOA but they are all eligible for GSP preferences. The product coverage in these regional programs is wider compared to GSP and rules of origin requirements are less restrictive. Thus, exporters from eligible countries generally utilize the CBI, AGOA and Andean provisions rather than those of the GSP. Finally, there are only three countries in our sample that enjoy FTA preferences as we stated above. FTA is the least restrictive and most comprehensive market access program due to GATT/WTO requirements and its reciprocal nature. That is why numerous countries from Chile to Singapore to current CBI members have been pursing FTAs with the US for years.

The main set of preference variables is comprised of dummy variables for eligibility in each program. We refer to it as Preference Status ${ }_{i j t k}$ and it takes the value of 1 if product category $j$ from country $i$ is eligible for preference program $k$ in year $t$. Although preference eligibility status of similar tariff lines are highly correlated, it is possible that only a portion

\footnotetext{
${ }^{10}$ This is not true for the GSP programs of the EU which discriminate further in favor of least developed countries.
} 
of the tariff lines in a product category (we have a total of 98) are eligible. In this case, we continue to assign a value of 1 if any of the tariff lines in a category are eligible for that program. This is not a major concern for FTA, CBI, Andean and AGOA since a wide majority of the tariff lines in a given category are either eligible together or not at all. However, this generalization poses a problem for GSP since the eligibility is more limited and idiosyncratic. We address this issue with the second group of preference variables as discussed below. In the end, we have 90 product categories eligible for GSP and all 98 eligible for FTA in both 1997 and 2001. For the other programs, the Trade Act of 2000 made certain changes. For example, while 87 and 88 categories were eligible for CBI and Andean, respectively, in 1997, all 98 categories were eligible in 2001. AGOA was not in effect in 1997 and covers all categories in 2001. Sample statistics are reported in Table 1b.

The second set of preference indicators aims to measure how valuable the preferences actually are. There is almost a consensus among policymakers that preferential programs are saddled with many restrictions in the form of rules of origin requirements that impede their utilization (see Brenton [2003] ). It is frequently reported that in many categories only around $30 \%$ of all eligible exports enter the US and EU under preferences (World Bank [2003]). As a result, the presence of a preference in a category does not mean much when the beneficiary country cannot take advantage of it. To address this problem, we construct a variable denoted as Preference Utilization $_{i j t k}$ and calculated as follows:

$$
\text { Preference Utilization }_{i j t k}=\left\{\begin{array}{c}
\frac{\sum_{i \in \kappa} C V_{i j t k}}{\sum_{i \in \kappa} \sum_{k} C V_{i j t k}} \text { if } i \in \kappa \\
0 \text { if } i \notin \kappa
\end{array}\right.
$$

where $\kappa$ denotes the set of countries eligible for preference program $k$ and $C V_{i j t k}$ is the customs value of exports from country $i$ in category $j$ under program $k$ in year $t$. Thus, $\sum_{i \in \kappa} C V_{i j t k}$ is the total imports of category $j$ in year $t$ that entered the U.S. under the program $k$ and $\sum_{i \in \kappa} C V_{i j t}$ is the total imports of the U.S. in category $j$ in year $t$ from all countries that are eligible under program $k$. Then, PreferenceUtilization ftk $_{\text {of }}$ program $k$ 
in category $j$ in year $t$ is the ratio of all exports entering under the program in that category to all exports from all eligible countries. If the country is not eligible for the program $k$, the variable is equal to zero. The variable is meant to be a measure of the overall utilization of the preference program in a given category and, therefore, is identical across all eligible countries. The average utilization ratios are reported in Table 1c. GSP has the lowest number with an average of 24.9\% in 1997 and $19.3 \%$ in 2001. Andean Program has an average of 33.3\% (and 24.8\%) while the CBI has 45.9\% (and 36.1\%) in 1997 (and 2001). FTAs have the largest utilization ratios of $63.3 \%$ and $58.1 \%$ in 1997 and 2001, respectively.

One might argue that we should use a country specific utilization ratio rather than an aggregate one since each beneficiary country has a different economic and technical capacity to overcome the barriers imposed by such rules. More specifically, smaller and poorer countries tend to have many disadvantages in this regard. However, our aim is to measure the overall effectiveness of the preference program in question. Furthermore, a country-specific variable would be correlated with the dependent variable, the total exports of the country in question, and create endogeneity problems.

\section{Estimation Results}

Table 2 shows the full sample estimates of the gravity equation with Preference Status dummies for each preference program - FTA, GSP, CBI, Andean and AGOA. We have product fixed effects to capture unobserved sectoral variations (such as product-specific MFN tariffs and non-tariff barriers) and use robust standard errors. The first column is the standard OLS estimation that is the norm in the literature. One of the main problems we face is that more than half of the observations have zero trade volumes, which can significantly bias the results. This issue simply arises because most countries, especially smaller developing countries, export only a few product lines. This might not be a severe problem in many cases where the focus is on aggregate trade volumes and large countries. However, it is likely that 
a significant portion of the observations will have zero trade volume if the gravity equation is estimated using a large number countries and/or product categories ${ }^{11}$.

Column 1 in Table 2 presents the results if we were to include all of these observations in the OLS estimation. Most coefficients have the expected and significant signs but their magnitudes are of suspect. For example, income, distance, common language and island have rather large coefficients. Transport costs, on the other hand, have a very large and positive sign. Thus it seems that the inclusion of zeros does creates severe biases in the estimates.

In order to avoid these biases, we first estimate the same gravity equation using only observations with positive trade volumes and the results are reported in column 2. An alternative is to use the TOBIT estimator, which is reported in column 3 for 1997. As can be seen, the results of the OLS estimation with positive observations are very close to the TOBIT estimation. This is also true for 2001 although we do not report it here. Therefore, we discuss the TOBIT results as we believe that is the more appropriate solution to dealing with zero-censored observations.

The corresponding TOBIT estimates show that all preference programs, except the GSP, have positive and significant effects on the exports of the beneficiaries. An FTA member exports almost three times more than a country with identical characteristics ${ }^{12}$. This number might be rather large since the FTA dummy is highly correlated with the border dummy all neighbors of the US have an FTA agreement and the only non-neighbor with an FTA is Israel. In contrast, the border dummy is not significant in our estimation which is generally not the case in the literature. So it is highly likely that the FTA variable is partially capturing the border effect ${ }^{13}$. CBI beneficiaries export $136 \%$ more and the same number for Andean

\footnotetext{
${ }^{11}$ As far we could see, Coe and Hoffmaister [1999] is one of the few papers which explicitly acknowledges this issue.

${ }^{12}$ This calculation comes from the fact that the model is estimated in log-log form, whereas the gravity model is originally a multiplicative model. So the estimated coefficients can be interpreted at the exponential ( "e" $=2.17 \ldots$ ) to the beta times the exports from non beneficiaries.

${ }^{13}$ European Union provides a more appropriate analysis of the FTA effect since it has a higher number of partner countries and does not share borders with large portion of them.
} 
countries is $42 \%$. On the other hand, GSP beneficiaries export $17 \%$ less. This counterintuitive result is consistent with the results reported by Ozden and Reinhardt [2003a and 2003b] on the negative effects of the GSP preferences on the recipients. These results indicate that preference programs positively affect the export volumes of the beneficiary countries relative to the excluded countries. Furthermore, the effect increases as the program becomes more generous and less restrictive.

We next look at the explanatory variables commonly used in trade gravity models. Log Income has a coefficient close to 1 and Log Income per Capita has a slightly negative but significant coefficient. These together imply that doubling of the GNP of an exporting country (while holding the population constant) doubles its exports to the US. This is predicted by most theoretical models constructed to support the gravity equation (Anderson [1979]; Feenstra et al. [2001]; Evenett and Keller [2002]). Distance has a negative coefficient and $1 \%$ increase in distance decreases trade volume by $0.4 \%$. Transport costs are even more important with a $1 \%$ increase leading to a decline of $2.1 \%$. English speaking countries' exports are $40 \%$ higher while Islands export $54 \%$ more. WTO membership do not seem to have an influence which is consistent with Rose [2003].

Column 4 reports the TOBIT estimates for 2001. The main difference is the inclusion of AGOA, which went into effect with the Trade Act of 2000. Surprisingly, the coefficient of AGOA is negative and significant. A close inspection reveals that this is due to the high negative correlation between the distance variable and the AGOA dummy - AGOA beneficiaries are, on average, $65 \%$ more distant to the US. The AGOA dummy is capturing the distance effect which becomes positive in this regression! The FTA coefficient is almost identical to the one from 1997 while the CBI and Andean dummies' coefficients increase. This is partially due to the expanded benefits of these programs in 2000 (especially the relaxation of the rules regarding apparel and several labor intensive sectors) and as well as the increased experience if the exporters in taking advantage of the preferences. Among the other variables, Area and Border are now significant. 


\subsection{Preference Utilization}

Our second set of results use the Preference Utilization Ratios, instead of the Preference Status Dummies, as the explanatory variables of interest. As explained above, Utilization Ratio of a specific preference program is the ratio of all exports that enter the United States under that program to all exports of the eligible countries. For example, it is possible that a product is eligible for preferences from the beneficiaries under the GSP provisions but none of the exporters use the preference and they prefer to pay the MFN tariffs. This might occur because the rules of origin requirements are restrictive or the paperwork is burdensome. In this case, the presence of the preference is meaningless and the Preference Status Dummy would not represent the actual effect. On the other hand, Utilization Ratios would be equal to zero and correctly capture the true effect.

Table 3 presents our TOBIT results when the Utilization Ratios replace Preference Status dummies. The results are similar to those discussed in the previous section in terms of the relative effects of different programs. Column 1 has the results for 1997 with product dummies. FTA and CBI have positive and significant coefficients whereas the Andean coefficient is not significant. A $1 \%$ increase in utilization increases trade by almost $1 \%$ in an FTA and by $1.2 \%$ in the CBI. However, in practice it seems that utilizing FTA preferences is easier than for CBI. In fact, the average utilization ratio in is $63 \%$ for FTAs and $46 \%$ in the CBI in 1997. Combined with the relevant coefficient estimates, these utilization rates imply that an average FTA member has around $82 \%$ higher exports to the US, as opposed to $75 \%$ for the average CBI beneficiary, compared to countries that pay MFN tariffs ${ }^{14}$. We believe these numbers more accurately capture the effects of preference programs, especially in the case of the FTA, compared to results from the previous section. The GSP coefficient is still negative and an average GSP beneficiary exports $35 \%$ less.

Another benefit of using utilization ratios is that the FTA utilization variable is not correlated with the border dummy. This probably contributes to the more reasonable results

\footnotetext{
${ }^{14}$ The average effects are calculated by $\exp ($ utilization ratio $*$ coef ficient $)-1$.
} 
and the border dummy becomes significant, consistent with the other results in the literature. The coefficients of the other gravity variables have the expected coefficients. Log Income and Log per Capita Income coefficients are close to unity as in the previous section. Sharing a common language and being an island increase trade by $52 \% 15$ and $38 \%$ respectively. On the other hand, $1 \%$ increases in distance and transportation costs decrease trade volumes by $0.55 \%$ and $2 \%$, respectively.

The results for 2001 are reported in column 2. The main difference is the addition of the AGOA utilization variable. Recall that the AGOA status dummy was correlated with the distance variable and that led to counter-intuitive results in the previous section. However, the coefficient of the AGOA utilization variable is now positive and significant. AGOA utilization variable has a mean of $0.4 \%$ but the trade weighted average is $45.6 \% 16$. If we use the former to evaluate AGOA, we see that the program leads to only $5 \%$ higher trade for an average beneficiary. Andean Utilization variable's coefficient is also significant and positive in 2001, especially compared to1997. This is probably due to the fact that the beneficiaries had time to adjust and learn to take advantage of the program in the preceding years. The net effect is that Andean program beneficiaries export $24 \%$ more than they would have without the preferences. The coefficients for FTA and CBI increased slightly but the average utilization are slightly lower so the average effect of both programs are the same in 2001. GSP coefficient is still negative but lower in value. Combined with the decline in the average utilization, the net negative effect of GSP is now 25\%. All of the other gravity variables' coefficient are similar in value to the results from 1997 . The only exception is the transport costs which indicates trade became more sensitive to these costs.

We try an alternative specification in columns 3 and 4 . Instead of various country specific gravity variables (such as log income, distance, language etc.), we include country dummies ${ }^{17}$

\footnotetext{
${ }^{15}$ This is calculated by $\exp (0.424)-1$.

${ }^{16}$ This is due to the fact that the two largest export categories from AGOA countries, oil and apparel, mostly enter the U.S. under the AGOA preferences and there is very little exports in other categories.

${ }^{17}$ We could not include country dummies in the previous section with Preference Status Dummies since these are also country specific.
} 
to capture these and other unobserved country-specific factors that might affect the volume of exports to the U.S. ${ }^{18}$. In the end, we are left with utilization variables and the transport costs variable. The results are quite similar to the previous ones. The biggest difference is with the coefficients of the CBI variable which is still positive and significant but much smaller in value for both years. According to these new estimates, the impact of CBI preferences is only an increase of $20 \%$ and $22 \%$ in 1997 and 2001, respectively, on the volume of exports to the U.S. This implies that certain omitted country specific variables were influencing the previous results.

\subsection{U.S. Geoolitical Interests and the Endogeneity of Preference Status}

Our next set of regressions address the potential role played by U.S. political interests in determining the which countries get preferential market access. This is generally an ignored issue in the analysis of the preferential trading arrangements, yet it is a critical one since the granting and removal of preference eligibility is, after all, a political decision. The first countries to sign FTAs with the US were both of its neighbors and one of its closest political allies. The CBI program is designed for the countries in the region that US considers strategically important. Andean trade preference program is an explicit tool in the fight against drugs in the beneficiary countries. On the other hand, removal from GSP is motivated by politics and other considerations quite frequently. For example, most of the important exports of Pakistan were removed from the GSP eligibility list during the crisis over its nuclear weapons tests. However, they were reinstated when the US needed Pakistani help

\footnotetext{
${ }^{18}$ We should note that our cross-section of countries and industries is similar to using panel data, but instead of time we have variation across industries. It is well known that in TOBIT models with fixed effects, the latter cannot be eliminated by differencing (across countries, in this case) or by the inclusion of dummies to capture heterogeneity of means. This is so because in truncated series, the fixed effects are not additive or multiplicative. The inclusion of fixed effects in this context thus introduces a bias in the structural parameters that is inversely proportional to the number of industries in this case (inversely proportional to the number of periods in panel data). Fortunately, in this application the number of industries is very high, which ensures that the resulting biases are negligible. See Honoré (1992) and Arellano and Honoré (2001).
} 
in Afghanistan.

Endogeneity may also arise if the recipient's trade policies affect the US decisions over granting of unilateral preferences. The American exporters who face difficulties in entering these countries' markets may pressure the US government to use these preferences as a leverage for reciprocal market access, although the preferences are supposed to be nonreciprocal. On the other hand, domestic import competing sectors in the US may lobby the government to remove the preferences from countries who have used them successfully to increase their exports to the US. This is part of the reason why these programs (CBI, GAP, Andean and AGOA) are created with limited duration and are reviewed every two years.

We use an instrumental variables (IV) approach to isolate the "treatment effect" of preferences on trade policy when the treatment or program eligibility itself is endogenous. That is, the granting of trade preferences by the U.S. can be expressed as a function of geostrategic interests:

$$
\text { Preference } e_{i, t}^{*}=\gamma^{\prime} \mathbf{x}_{i, t-1}+u_{i, t}
$$

Since this technique allows only one endogenous variable, we first treat CBI, Andean and AGOA as one program, instead of separate programs as we did previously. We keep separate dummies for GSP and FTA where we assume they are exogenous. We have Preference ${ }_{i, t}=1$ if Preference $e_{i, t}^{*}>0$ but 0 otherwise, and $\mathbf{x}$ is a vector of instruments thought to be uncorrelated with $\varepsilon$ in equation (1). Because of the discrete nature of Preference Status, the usual 2SLS instrumental variables method may overstate the coefficient estimates. Instead, we use the well-known "treatment effects" instrumental variables (IV) approach, much like a Heckman selection model but with observed trade policy outcomes even for those countries not receiving the "treatment" - CBI, Andean, AGOA in this case. This model assumes $\varepsilon_{i, t}$ in (1) and $u_{i, t}$ in (5) are correlated, and we estimate it using maximum likelihood (Greene [2000]). We thus use values of Preference ${ }_{i, t}$ fitted from a first-stage probit regression as the optimal instrument for Preference Status $i_{i, t}$ in equation (1). We report traditional heteroscedastic-consistent standard errors. 
Özden and Reinhardt [2002] demonstrate that there are a number of good predictors of US preference eligibility. These include (a) distance from country $i$ to the United States; (b) a dummy indicating country $i$ maintains a formal alliance with the United States ${ }^{19}$; (c) average annual US total aid per capita to the country during the previous decade; (d) the geographic location of the country - dummy varaibles for the continental location. We should note that the US is likely to grant preference eligibility when it also has political alliances with a target country and likely to remove preferences along with other political sanctions, a criterion explicitly written into the preference-authorizing statutes.

Table 4 presents the IV estimates of the main equation. Our results are similar to the ones in table 2 which provides the appropriate comparison. Column 1 is for 2001 and the CBI/Andean/AGOA coefficient is positive and significant. The results indicate that being a CBI/Andean/AGOA beneficiary increases your exports to the US by more than $3(\exp (1.115))$ times in 2001. Furthermore, the FTA's impact is even larger than $\mathrm{CBI} /$ Andean/AGOA. The coefficients of the gravity variables have the predicted signs and values closer to previous estimations. All of the variables in the first stage probit estimation have the predicted and highly significant coefficients as can be seen at the bottom of the table $^{20}$.

In the next stage, we assume that FTA eligibility is also determined by geostrategic interests, thus we treat it together with CBI, Andean, and AGOA. Our new variable takes the value 1 if a country is eligible for any of these four programs ${ }^{21}$. Column 2 presents the results for 2001 and these are very similar to the previous column. Eligibility in these programs increases the exports of the member countries by more than 3 times in 2001.

\footnotetext{
${ }^{19}$ Distance and alliance data are from the Correlates of War Project as distributed by Bennett and Stam [2000], updated by the authors to 2000 .

${ }^{20}$ We did not report the coefficients of the continent dummies from the first stage regression. These are also all significant.

${ }^{21}$ Estimates from auxiliary Ordered Probit regressions for eligibility for these programs indicate that one cannot reject the hypothesis that the probability of receiving FTA preference is determined by the same threshold values of the explanatory variables used in the selection equation (and in the Probit equation of the treatment regressions) as those that determine the probability of being elegible for the other programs (CBI/Andean/AGOA).
} 
Although the coefficients have the predicted signs, these results, we believe, have an upward bias and further analysis is needed. Unfortunately, utilization ratios can not be used in this context since the treatment variable needs to be a dummy variable.

\subsection{Endogeneity of Utilization Ratios}

A selection bias continues to be present when we use the utilization ratios as the proxy for the extent of preferential market access. In this case, the problem is also related to political and strategic considerations that influence the granting of preferences. However, we face an additional data censoring bias since the preferential exports, hence the utilization ratios, are only observed for countries and products that are eligible.

A different econometric approach is required to provide consistent estimates of the impact of program utilization ratios on the exports to the U.S. Since the bias is due to sample censoring, we follow Heckman (1979) in estimating a sample selection equation simultaneously with the corresponding linear model of exports to the U.S. via maximum likelihood. The "selection equation" is the same as the Probit equation in the treatment models discussed above. However, the exports model is estimated with the sub-sample of countries and products that are eligible for preferential treatment.

Table 5 reports the results derived from the Heckman-selection models. We report two sets of results. Both use the same selection equation as the one used in the treatment regressions, but the second excludes the dummy variable for sharing a common border with the U.S. (i.e., Canada and Mexico) from the log-linear exports equation. This specification produced slightly different results that are worth discussing.

Both specifications indicate that the utilization of FTAs, CBI, and AGOA have positive and significant effects on exports to the U.S., whereas GSP and ANDEAN do not. The main difference between the two specifications is that the impact of the FTAs is much smaller in the model that includes the common-border variable. These results suggest that the 
impact of NAFTA (the FTA benefitting Canada and Mexico) is a bit difficult to distinguish from the common border effect. This distinction is made more difficult by the fact that a common border is in itself an important determinant of the decision by the U.S. to offer such trade preferences which is suggested by the significant effect that this variable has on the probability of being eligible for trade preferences.

It is worth comparing the results of the regular TOBIT estimation (column 2 of Table 3) with the Heckman selection model (Column 1 Table 5) to identify the effects of the selection bias. The most important result is that the coefficients of the FTA, CBI and Andean utilization varaibles are significantly lower in the Heckman Selection model. For example, the estimates for the impact goes from $84 \%$ to $50 \%$ for the FTAs and from $33 \%$ to $3 \%$ for CBI (when we use average utilization ratios) and the Andean program is no longer significant. On the other hand, the estimated effects of the GSP and AGOA are higher under the Heckman selection model; GSP no longer has a negative effect and AGOA's effect doubled. These results suggest that FTA/CBI/Andean beneficiaries are actually benefitting more from the political alliance variables in the selection equation, and the preferences themselves seem to be an endogenous response to these geo-strategic considerations. The opposite is probably at play with respect to the rather large number of countries that benefit from GSP and AGOA.

\section{Conclusion}

The main objective of this paper was to identify the impact of various U.S. reciprocal and unilateral preferential market access programs while at the same time control for the geostrategic motivations of the U.S. Our main conclusion is that such programs have economically large and statistically significant effects on the exports of the beneficiary countries, but geostrategic and political interests play an important role in determining the probability of gaining preferential access to U.S. markets. In fact, some of the commonplace results reported in the existing literature seem to be biased by the exclusion of these non-economic considerations. For example, exporting countries' geographic distance from the U.S. is not a significant 
determinant of exports to this market in the context of the treatment effects regressions, where the probability of being eligible for preferential access is endogenously determined by U.S. geostrategic interests. The significance of distance reappeared in the Heckman-selection models where program utilization is determined by U.S. non-economic motivations, but in this case the estimated effect of the Andean trade preferences was not significant.

Of particular current interest is the finding that FTA members have significantly larger exports to the U.S. compared to excluded countries. And this effect seems to be larger than the also positive effects of CBI, ANDEAN, and AGOA. Another important finding is that the estimated benefits of preferential market access programs decline considerably when we take into account the rules of origin requirements and other bureaucratic barriers by using utilization ratios in the estimations. GSP is the only exception in terms of providing benefits to beneficiaries and seems to have negative effects in several specifications.

Among the interesting methodological conclusions, the presence of zeroes in the productlevel exports data tends to produce severe biases in linear estimations. These biases are particularly influential on the estimated coefficients of some preferential programs, AGOA in particular, and they also severely biased the impact of distance in the OLS linear regression. Thus truncated data techniques seem to be more appropriate in this type of application.

The inclusion of a direct proxy for international transport and transactions costs seems to be quite important in these models. Indeed, all of our estimates of the impact of these costs on trade volumes indicate that they are economically and statistically important. Moreover, in the treatment regressions, which also control for the endogeneity of program eligibility, the distance variable became statistically irrelevant, whereas the direct proxy of international transport and transactions costs remained robustly significant with economically large coefficients.

Undoubtedly, there is need for further analysis of the effects of preference programs and more to be learned from gravity models in this context. One main limitation of this study is the focus on U.S. programs. The European Union has similar reciprocal and unilateral 
preference programs in place with a large portion of its trading partners. Furthermore, the EU programs have different eligibility rules and differing preference margins for each country and their study is bound provide additional insights.

\section{$6 \quad$ Tables and Figures}

\begin{tabular}{||c|c|c|c|c|c||}
\hline \hline \multicolumn{7}{|c|}{ Table 1a. Sample Statistics } \\
\hline \hline & $\begin{array}{c}\text { \# of positive } \\
\text { observations }\end{array}$ & Mean & St. Dev. & Min & Max \\
\hline Log of Trade Volume -1997 & 7577 & 13.311 & 3.628 & 5.525 & 24.514 \\
\hline Log of Trade Volume -2001 & 7744 & 13.502 & 3.620 & 5.533 & 24.648 \\
\hline Transport Costs - 1997 & 7300 & 0.0914 & 0.111 & 0.000 & 1.811 \\
\hline Transport Costs - 2001 & 7665 & 0.0905 & 0.102 & 0.000 & 1.386 \\
\hline \hline & & & & & \\
\hline & $\begin{array}{c}\text { \# of countries } \\
\text { w/ data }\end{array}$ & Mean & St. Dev. & Min & Max \\
\hline Log of Income - 1997 & 155 & 22.805 & 2.461 & 17.180 & 29.349 \\
\hline Log of Income - 2001 & 153 & 22.925 & 2.478 & 17.310 & 29.362 \\
\hline $\begin{array}{c}\text { Log of Per } \\
\text { capita Income - 1997 }\end{array}$ & 155 & 7.582 & 1.982 & 3.001 & 10.675 \\
\hline $\begin{array}{c}\text { Log of Per } \\
\text { capita Income - 2001 }\end{array}$ & 153 & 7.536 & 1.545 & 4.445 & 10.941 \\
\hline Log of Distance & 163 & 8.639 & 0.496 & 6.981 & 9.434 \\
\hline Log of Area & 166 & 23.928 & 8.008 & 1.871 & 32.196 \\
\hline Border & 173 & 0.011 & 0.498 & 0 & 1 \\
\hline WTO membership -1997 & 173 & 0.821 & 0.384 & 0 & 1 \\
\hline WTO membership -2001 & 173 & 0.879 & 0.328 & 0 & 1 \\
\hline Common Language & 173 & 0.364 & 0.483 & 0 & 1 \\
\hline Island & 173 & 0.294 & 0.457 & 0 & 1 \\
\hline \hline
\end{tabular}




\begin{tabular}{||c|c|c||}
\hline \hline \multicolumn{3}{|c||}{ Table 1b. Sample Statistics } \\
\hline \hline Programs & $\begin{array}{c}\text { \# of eligible } \\
\text { countries }\end{array}$ & $\begin{array}{c}\text { \# of eligible } \\
\text { categories }\end{array}$ \\
\hline TOTAL & 173 & 98 \\
\hline GSP & 127 & 90 \\
\hline FTA & 3 & 98 \\
\hline CBI - 1997 & 21 & 87 \\
\hline CBI - 2001 & 21 & 98 \\
\hline ANDEAN - 1997 & 4 & 88 \\
\hline ANDEAN -2001 & 4 & 98 \\
\hline AGOA & 33 & 98 \\
\hline \hline
\end{tabular}

\begin{tabular}{||c|c|c|c|c|c||}
\hline \hline \multicolumn{7}{|c|}{ Table 1c. Sample Statistics } \\
\hline \hline $\begin{array}{c}\text { Utilization } \\
\text { Ratios }\end{array}$ & $\begin{array}{c}\text { \# of eligible } \\
\text { categories }\end{array}$ & Mean & $\begin{array}{c}\text { Mean weighted } \\
\text { by trade volume }\end{array}$ & Min & Max \\
\hline GSP - 1997 & 11430 & 0.249 & 0.137 & 0 & 0.901 \\
\hline GSP - 2001 & 11430 & 0.193 & 0.107 & 0 & 0.761 \\
\hline FTA - 1997 & 294 & 0.633 & 0.595 & 0 & 0.993 \\
\hline FTA - 2001 & 294 & 0.581 & 0.547 & 0 & 0.996 \\
\hline CBI - 1997 & 1827 & 0.459 & 0.358 & 0 & 1 \\
\hline CBI - 2001 & 2058 & 0.361 & 0.419 & 0 & 0.990 \\
\hline ANDEAN - 1997 & 352 & 0.333 & 0.163 & 0 & 1 \\
\hline ANDEAN -2001 & 392 & 0.248 & 0.175 & 0 & 1 \\
\hline AGOA & 3234 & 0.004 & 0.456 & 0 & 1 \\
\hline \hline
\end{tabular}




\begin{tabular}{|c|c|c|c|c|}
\hline \multicolumn{5}{|c|}{ Table 2. Programs Presented as Dummies } \\
\hline Model: & $\begin{array}{c}\text { OLS } \\
\text { All } \\
\text { observations }\end{array}$ & $\begin{array}{c}\text { OLS } \\
\text { Only Positive } \\
\text { Observations }\end{array}$ & TOBIT & TOBIT \\
\hline Year & 1997 & 1997 & 1997 & 2001 \\
\hline Constant & $\begin{array}{c}-20.074^{* *} \\
(1.391)\end{array}$ & $\begin{array}{c}-9.351^{* *} \\
(1.426)\end{array}$ & $\begin{array}{c}-12.342^{* *} \\
(1.235)\end{array}$ & $\begin{array}{c}-16.463^{* *} \\
(1.455)\end{array}$ \\
\hline GSP & $\begin{array}{c}-0.646^{* *} \\
(0.093)\end{array}$ & $\begin{array}{l}-0.208^{*} \\
(0.089)\end{array}$ & $\begin{array}{l}-0.182^{*} \\
(0.082)\end{array}$ & $\begin{array}{l}-0.144 \\
(0.083)\end{array}$ \\
\hline FTA & $\begin{array}{l}3.865^{* *} \\
(0.342)\end{array}$ & $\begin{array}{l}1.612^{* *} \\
(0.276)\end{array}$ & $\begin{array}{l}1.586^{* *} \\
(0.260)\end{array}$ & $\begin{array}{l}1.601^{* *} \\
(0.250)\end{array}$ \\
\hline CBI & $\begin{array}{c}0.136 \\
(0.206)\end{array}$ & $\begin{array}{l}0.685^{* *} \\
(0.182)\end{array}$ & $\begin{array}{l}0.859^{* *} \\
(0.163)\end{array}$ & $\begin{array}{l}1.554^{* *} \\
(0.180)\end{array}$ \\
\hline ANDEAN & $\begin{array}{c}0.736 \\
(0.279)\end{array}$ & $\begin{array}{c}0.268 \\
(0.175)\end{array}$ & $\begin{array}{c}0.354^{*} \\
(0.163)\end{array}$ & $\begin{array}{l}0.581^{* *} \\
(0.157)\end{array}$ \\
\hline AGOA & - & - & - & $\begin{array}{c}-0.811^{* *} \\
(0.107)\end{array}$ \\
\hline Log of Income & $\begin{array}{l}1.991^{* *} \\
(0.021)\end{array}$ & $\begin{array}{l}1.059^{* *} \\
(0.019)\end{array}$ & $\begin{array}{l}1.048^{* *} \\
(0.017)\end{array}$ & $\begin{array}{l}1.015^{* *} \\
(0.019)\end{array}$ \\
\hline $\begin{array}{c}\text { Log of Per } \\
\text { capita Income }\end{array}$ & $\begin{array}{c}-0.022^{* *} \\
(0.023)\end{array}$ & $\begin{array}{c}-0.051^{* *} \\
(0.018)\end{array}$ & $\begin{array}{c}-0.064^{* *} \\
(0.018)\end{array}$ & $\begin{array}{c}-0.072^{*} \\
(0.030)\end{array}$ \\
\hline Log of Distance & $\begin{array}{c}-2.499^{* *} \\
(0.139)\end{array}$ & $\begin{array}{c}-0.524^{* *} \\
(0.132)\end{array}$ & $\begin{array}{c}-0.407^{* *} \\
(0.115)\end{array}$ & $\begin{array}{l}0.487^{* *} \\
(0.142)\end{array}$ \\
\hline Log of Area & $\begin{array}{l}-0.033 \\
(0.007)\end{array}$ & $\begin{array}{c}0.013 \\
(0.007)\end{array}$ & $\begin{array}{c}0.014 \\
(0.006)\end{array}$ & $\begin{array}{l}0.037^{* *} \\
(0.007)\end{array}$ \\
\hline Border & $\begin{array}{l}-2.983 \\
(0.453)\end{array}$ & $\begin{array}{c}0.580 \\
(0.360)\end{array}$ & $\begin{array}{c}0.535 \\
(0.348)\end{array}$ & $\begin{array}{l}1.491^{* *} \\
(0.358)\end{array}$ \\
\hline WTO Membership & $\begin{array}{c}0.089 \\
(0.099)\end{array}$ & $\begin{array}{l}-0.068 \\
(0.102)\end{array}$ & $\begin{array}{l}-0.062 \\
(0.096)\end{array}$ & $\begin{array}{c}0.113 \\
(0.121)\end{array}$ \\
\hline Common Language & $\begin{array}{l}0.788^{* *} \\
(0.096)\end{array}$ & $\begin{array}{l}0.329^{* *} \\
(0.088)\end{array}$ & $\begin{array}{l}0.342^{* *} \\
(0.080)\end{array}$ & $\begin{array}{l}0.247^{* *} \\
(0.080)\end{array}$ \\
\hline Island & $\begin{array}{l}1.440^{* *} \\
(0.104)\end{array}$ & $\begin{array}{l}0.520^{* *} \\
(0.102)\end{array}$ & $\begin{array}{l}0.431^{* *} \\
(0.093)\end{array}$ & $\begin{array}{l}0.200^{*} \\
(0.094)\end{array}$ \\
\hline Transport Costs & $\begin{array}{l}7.273^{* *} \\
(1.325)\end{array}$ & $\begin{array}{c}-2.609^{* *} \\
(0.388)\end{array}$ & $\begin{array}{l}-2.10^{* *} \\
(0.167)\end{array}$ & $\begin{array}{c}-5.969^{* *} \\
(0.341) \\
\end{array}$ \\
\hline Observations & 15190 & 7365 & 15190 & 14994 \\
\hline $\bar{R}^{2}$ & 0.629 & 0.538 & 0.148 & 0.1617 \\
\hline Product Fixed Effects & Yes & 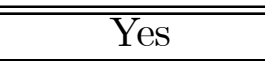 & $\overline{\overline{Y e s}}$ & $\overline{\overline{Y e s}}$ \\
\hline
\end{tabular}

Regressand: natural log of trade volume

First two columns are OLS w/ product fixed effects and robust standard errors.

Last two columns are TOBIT w/ robust standard errors. 


\begin{tabular}{|c|c|c|c|c|}
\hline \multicolumn{5}{|c|}{ Table 3. Programs Presented as Utilization Ratios } \\
\hline Model: & TOBIT & TOBIT & TOBIT & TOBIT \\
\hline & 1997 & 2001 & 1997 & 2001 \\
\hline Constant & $\begin{array}{c}-9.903^{* *} \\
(0.978)\end{array}$ & $\begin{array}{c}-8.131^{* *} \\
(0.984)\end{array}$ & $\begin{array}{c}11.123^{* *} \\
(0.514)\end{array}$ & $\begin{array}{c}10.989^{* *} \\
(0.526)\end{array}$ \\
\hline GSP & $\begin{array}{c}-1.750^{* *} \\
(0.191)\end{array}$ & $\begin{array}{c}-1.458^{* *} \\
(0.236)\end{array}$ & $\begin{array}{l}-2.025^{* *} \\
(0.212)\end{array}$ & $\begin{array}{c}-1.731^{* *} \\
(0.252)\end{array}$ \\
\hline FTA & $\begin{array}{l}0.951^{* *} \\
(0.282)\end{array}$ & $\begin{array}{l}1.052^{* *} \\
(0.281)\end{array}$ & $\begin{array}{l}0.831^{*} \\
(0.351) \\
\end{array}$ & $\begin{array}{l}0.944^{* *} \\
(0.331)\end{array}$ \\
\hline CBI & $\begin{array}{l}1.218^{* *} \\
(0.207)\end{array}$ & $\begin{array}{l}1.349^{* *} \\
(0.221)\end{array}$ & $\begin{array}{l}0.408^{*} \\
(0.207)\end{array}$ & $\begin{array}{l}0.516^{*} \\
(0.237)\end{array}$ \\
\hline ANDEAN & $\begin{array}{c}0.480 \\
(0.323)\end{array}$ & $\begin{array}{l}0.863^{*} \\
(0.355)\end{array}$ & $\begin{array}{c}0.302 \\
(0.401)\end{array}$ & $\begin{array}{l}0.836^{*} \\
(0.420)\end{array}$ \\
\hline AGOA & - & $\begin{array}{l}1.263^{* *} \\
(0.407)\end{array}$ & - & $\begin{array}{l}1.243^{* *} \\
(0.393)\end{array}$ \\
\hline Log of Income & $\begin{array}{l}1.022^{* *} \\
(0.016)\end{array}$ & $\begin{array}{l}1.046^{* *} \\
(0.018)\end{array}$ & - & - \\
\hline $\begin{array}{c}\text { Log of Per } \\
\text { capita Income }\end{array}$ & $\begin{array}{c}-0.093^{* *} \\
(0.017)\end{array}$ & $\begin{array}{c}-0.144^{* *} \\
(0.027)\end{array}$ & - & - \\
\hline Log of Distance & $\begin{array}{l}-0.557^{* *} \\
(0.088)\end{array}$ & $\begin{array}{c}-0.422^{* *} \\
(0.089)\end{array}$ & - & - \\
\hline Log of Area & $\begin{array}{c}0.006 \\
(0.006)\end{array}$ & $\begin{array}{c}0.002 \\
(0.006)\end{array}$ & - & - \\
\hline Border & $\begin{array}{l}1.163^{* *} \\
(0.268)\end{array}$ & $\begin{array}{l}1.228^{* *} \\
(0.255)\end{array}$ & - & - \\
\hline WTO Membership & $\begin{array}{l}-0.001 \\
(0.095)\end{array}$ & $\begin{array}{l}0.123 \\
(0.119)\end{array}$ & - & - \\
\hline Common Language & $\begin{array}{l}0.424^{* *} \\
(0.078)\end{array}$ & $\begin{array}{l}0.238^{* *} \\
(0.075)\end{array}$ & - & - \\
\hline Island & $\begin{array}{l}0.321^{* *} \\
(0.092)\end{array}$ & $\begin{array}{l}0.337^{* *} \\
(0.091)\end{array}$ & - & - \\
\hline Transport Costs & $\begin{array}{c}-2.051^{* *} \\
(0.167) \\
\end{array}$ & $\begin{array}{c}-5.982^{* *} \\
(0.342) \\
\end{array}$ & $\begin{array}{c}-1.904^{* *} \\
(0.153)\end{array}$ & $\begin{array}{c}-5.962^{* *} \\
(0.327) \\
\end{array}$ \\
\hline Observations & 15190 & 14994 & 16954 & 16954 \\
\hline $\bar{R}^{2}$ & 0.149 & 0.160 & 0.221 & 0.249 \\
\hline Product dummies & 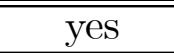 & yes & 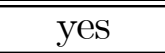 & $\overline{\text { yes }}$ \\
\hline Country dummies & no & no & yes & yes \\
\hline
\end{tabular}




\begin{tabular}{|c|c|c|}
\hline \multicolumn{3}{|c|}{ Table 4. Treatment Effects Models } \\
\hline Model: & $\begin{array}{l}\text { Treatment } \\
\text { Separate }\end{array}$ & $\begin{array}{l}\text { Treatment } \\
\text { Combined }\end{array}$ \\
\hline & 2001 & 2001 \\
\hline Constant & $\begin{array}{c}-17.028^{* *} \\
(1.563)\end{array}$ & $\begin{array}{c}-15.773^{* *} \\
(1.426)\end{array}$ \\
\hline GSP & $\begin{array}{c}-0.102 \\
(0.089)\end{array}$ & $\begin{array}{l}-0.089 \\
(0.088)\end{array}$ \\
\hline FTA & $\begin{array}{l}1.591^{* *} \\
(0.257)\end{array}$ & N/A \\
\hline CBI / ANDEAN / AGOA & $\begin{array}{l}1.115^{* *} \\
(0.184)\end{array}$ & $\mathrm{N} / \mathrm{A}$ \\
\hline ALL PREFERENCES & $\mathrm{N} / \mathrm{A}$ & $\begin{array}{l}1.286^{* *} \\
(0.154)\end{array}$ \\
\hline Log of Income & $\begin{array}{l}1.063^{* *} \\
(0.021)\end{array}$ & $\begin{array}{l}1.061^{* *} \\
(0.021)\end{array}$ \\
\hline $\begin{array}{l}\text { Log of Per } \\
\text { capita Income }\end{array}$ & $\begin{array}{l}-0.017 \\
(0.034)\end{array}$ & $\begin{array}{c}0.000 \\
(0.033)\end{array}$ \\
\hline Log of Distance & $\begin{array}{c}0.029 \\
(0.153)\end{array}$ & $\begin{array}{c}0.154 \\
(0.132)\end{array}$ \\
\hline Log of Area & $\begin{array}{l}0.024^{* *} \\
(0.007)\end{array}$ & $\begin{array}{l}0.024^{* *} \\
(0.008)\end{array}$ \\
\hline Border & $\begin{array}{l}1.217^{* *} \\
(0.369)\end{array}$ & $\begin{array}{l}1.719^{* *} \\
(0.173)\end{array}$ \\
\hline WTO Membership & $\begin{array}{l}-0.086 \\
(0.133)\end{array}$ & $\begin{array}{l}-0.079 \\
(0.132)\end{array}$ \\
\hline Common Language & $\begin{array}{c}0.122 \\
(0.084)\end{array}$ & $\begin{array}{c}0.107 \\
(0.084)\end{array}$ \\
\hline Island & $\begin{array}{l}0.417^{* *} \\
(0.106)\end{array}$ & $\begin{array}{l}0.396^{* *} \\
(0.105)\end{array}$ \\
\hline Transport Costs & $\begin{array}{l}-5.603^{* *} \\
(0.353)\end{array}$ & $\begin{array}{l}-5.592^{* *} \\
(0.353)\end{array}$ \\
\hline Probit Equation & & \\
\hline Constant & $\begin{array}{c}33.208^{* *} \\
(1.997)\end{array}$ & $\begin{array}{c}31.289^{* *} \\
(2.664)\end{array}$ \\
\hline Log of Distance & $\begin{array}{l}-5.291^{* *} \\
(0.172)\end{array}$ & $\begin{array}{l}-5.465^{* *} \\
(0.199)\end{array}$ \\
\hline Political alliance & $\begin{array}{l}2.033^{* *} \\
(0.137)\end{array}$ & $\begin{array}{c}0.069 \\
(0.250)\end{array}$ \\
\hline US Aid Per Capita & $\begin{array}{l}1.567^{* *} \\
(0.159) \\
\end{array}$ & $\begin{array}{l}2.191^{* *} \\
(0.227) \\
\end{array}$ \\
\hline Border & $\begin{array}{c}-12.248^{* *} \\
(0.241)\end{array}$ & $\begin{array}{l}2.232^{* *} \\
(0.191)\end{array}$ \\
\hline Observations & 7203 & 7203 \\
\hline
\end{tabular}




\begin{tabular}{|c|c|c|}
\hline \multirow{2}{*}{$\begin{array}{l}\text { Table 5. Heckma } \\
\text { Model: }\end{array}$} & $\overline{\text { Selection Models }}$ & $\overline{\text { Utilization Ratios }}$ \\
\hline & $\begin{array}{l}\text { Selection Model } \\
\text { w/ Border Effect }\end{array}$ & $\begin{array}{c}\text { Selection Model } \\
\text { w/out Border Effect }\end{array}$ \\
\hline \multirow[b]{2}{*}{ Constant } & $\begin{array}{ll}2001 \\
\end{array}$ & 22001 \\
\hline & $\begin{array}{c}-3.452^{*} \\
(2.041)\end{array}$ & $\begin{array}{l}-8.231^{* *} \\
(1.681)\end{array}$ \\
\hline GSP & $\begin{array}{c}0.024 \\
(0.624)\end{array}$ & $\begin{array}{l}-0.516 \\
(0.608)\end{array}$ \\
\hline FTA & $\begin{array}{l}0.696^{*} \\
(0.406)\end{array}$ & $\begin{array}{l}1.753^{* *} \\
(0.325)\end{array}$ \\
\hline CBI & $\begin{array}{l}0.780^{* *} \\
(0.276)\end{array}$ & $\begin{array}{l}0.525^{*} \\
(0.275)\end{array}$ \\
\hline ANDEAN & $\begin{array}{c}0.387 \\
(0.421)\end{array}$ & $\begin{array}{c}0.164 \\
(0.413)\end{array}$ \\
\hline AGOA & $\begin{array}{l}2.027^{* *} \\
(0.582)\end{array}$ & $\begin{array}{l}1.970^{* *} \\
(0.569)\end{array}$ \\
\hline Log of Income & $\begin{array}{l}0.943^{* *} \\
(0.048)\end{array}$ & $\begin{array}{l}0.996^{* *} \\
(0.048)\end{array}$ \\
\hline $\begin{array}{l}\text { Log of Per } \\
\text { capita Income }\end{array}$ & $\begin{array}{c}0.099 \\
(0.064)\end{array}$ & $\begin{array}{l}0.127^{*} \\
(0.063)\end{array}$ \\
\hline Log of Distance & $\begin{array}{l}-0.831^{* *} \\
(0.137)\end{array}$ & $\begin{array}{l}-0.937^{* *} \\
(0.129)\end{array}$ \\
\hline Log of Area & $\begin{array}{l}0.036^{*} \\
(0.019)\end{array}$ & $\begin{array}{c}0.005 \\
(0.017)\end{array}$ \\
\hline Border & $\begin{array}{l}1.753^{* *} \\
(0.382)\end{array}$ & $\mathrm{N} / \mathrm{A}$ \\
\hline WTO Membership & $\begin{array}{c}0.299 \\
(0.326)\end{array}$ & $\begin{array}{c}0.126 \\
(0.333)\end{array}$ \\
\hline Common Language & $\begin{array}{l}-0.091 \\
(0.129)\end{array}$ & $\begin{array}{c}0.019 \\
(0.128)\end{array}$ \\
\hline Island & $\begin{array}{l}-0.195 \\
(0.197)\end{array}$ & $\begin{array}{l}-0.071 \\
(0.198)\end{array}$ \\
\hline Transport Costs & $\begin{array}{l}-5.731^{* *} \\
(0.470)\end{array}$ & $\begin{array}{l}-5.825^{* *} \\
(0.477)\end{array}$ \\
\hline \multicolumn{3}{|l|}{ Selection Equation } \\
\hline Constant & $\begin{array}{l}.489^{* *} \\
(0.504)\end{array}$ & $\begin{array}{l}5.127^{* *} \\
(0.664)\end{array}$ \\
\hline Log of Distance & $\begin{array}{l}-1.467^{* *} \\
(0.083)\end{array}$ & $\begin{array}{l}-1.451^{* *} \\
(0.085)\end{array}$ \\
\hline Political alliance & $\begin{array}{l}0.467^{* *} \\
(0.029)\end{array}$ & $\begin{array}{l}0.471^{* *} \\
(0.028)\end{array}$ \\
\hline US Aid Per Capita & $\begin{array}{l}0.325^{* *} \\
(0.032)\end{array}$ & $\begin{array}{l}0.327^{* *} \\
(0.032)\end{array}$ \\
\hline Border & $\begin{array}{l}5.558^{* *} \\
(0.095)\end{array}$ & $\begin{array}{l}4.988^{* *} \\
(0.084)\end{array}$ \\
\hline Observations & 7253 & 7253 \\
\hline
\end{tabular}




\section{Bibliography}

\section{References}

[1] Aitken, N. D. [1973], " The Effect of EEC and EFTA on European Trade: A Temporal Cross-Section Analysis," American Economic Review, vol.63, p.881-92

[2] Anderson, James [1979], "A Theoretical Foundation for the Gravity Equation," American Economic Review, vol.69, p.106-116

[3] Anderson, James and Eric van Wincoop [2003a], "Gravity with Gravitas: A Solution to the Border Puzzle," American Economic Review, vol.93, p.170-92

[4] Anderson, James and Eric van Wincoop [2003b], "Trade Costs," mimeo, Boston College

[5] Bergstrand, Jeffrey [1989], "The Generalized Gravity Equation, Monopolistic Competition and the Factor-Proportions Theory in International Trade," Review of Economics and Statistics, vol.72, p.143-53

[6] Brenton, Paul [2003], "Integrating the Developing Countries into the World Trading System: The Current Impact of EU Preferences under Everything But Arms," Policy Research Working Paper 3018, World Bank, Washington DC

[7] Coe, David T. and Alexander W. Hoffmaister [1999], "North-South Trade: Is Africa Unusual?," Journal of African Economies, v.8, p.228-56

[8] Eaton, Jonathan and Samuel Kortum [2002], "Technology, Geography and Trade," Econometrica, vol.70, p.1741-1779

[9] Estevadeordal, Antoni [2000], "Negotiating Preferential Market Access: The Case of the NAFTA," Journal of World Trade, vol.34

[10] Evenett, Simon and Wolfgang Keller [2002], "On Theories Explaning the Success of the Gravity Equation, " Journal of Political Economy, vol.110, p.281-316

[11] Feenstra, Robert C. [2002], "Border Effects and the Gravity Equation: Consistent Methods for Estimation," Scottish Journal of Political Economy, v.49, 491-506

[12] Feenstra, Robert, James Markusen, and Andrew Rose [2001], " Using the Gravity Equation to Differentiate Among Alternative Theories of Trade," Canadian Journal of Economics, vol.34, p.430-47.

[13] Frankel, Jeffrey, [1997] Regional Trading Blocs in the World Economic System, Institue for International Economics, Washington D.C.

[14] Frankel, Jeffrey, Ernesto Stein and Shang-jin Wei, [1995] "Trading Blocs and the Americas: The Natural, the Unnatural and the Super-natural," Journal of Development Economics, Vol.47, p.61-95 
[15] Greenaway, David and Chris Milner [2002], "Regionalism and Gravity," Scottish Journal of Political Economy, Vol.49, p.574-85

[16] Heckman, James [1979], "Sample Selection Bias as a Specification Error," Econometrica, vol.47, p.153-61

[17] Krishna, Pravin, Jagdish Bhagwati and Arvind Panagariya [1999], Trading Blocs: Alternative Approaches to Analyzing Preferential Trade Agreements, MIT Press, Cambridge and London.

[18] Schiff, Maurice and Alan Winters [2003], Regional Integration and Development, World Bank and Oxford University Press, Washington D.C.

[19] Soloaga, Isidro and Alan Winters [2001], "Regionalism in the Nineties: What Effect on Trade?," North American Journal of Economics and Finance, vol.12, p.1-29

[20] World Bank [2003], Global Economic Prospects: Realizing the Promise of the Doha Agenda, World Bank, Washington DC. 